\title{
Induction of necrosis factor- $\alpha$ and interleukin-6 in mice in vivo and in murine peritoneal macrophages and human whole blood cells in vitro by Micrococcus luteus teichuronic acids
}

\author{
T. MONODANE, Y. KAWABATA:, S. YANG*, S. HASE $\dagger$ and H. TAKADA*
}

Department of Microbiology and Immunology, Kagoshima University Dental School, Kagoshima 890-8544,

* Department of Microbiology and Immunology, Tohoku University School of Dentistry, Sendai 980-8575 and

$\uparrow$ Department of Chemistry, Graduate School of Science, Osaka University, Toyonka 560-0043, Japan

\begin{abstract}
Earlier studies showed that Micrococcus luteus cells and cell walls induced anaphylactoid reactions leading to death, in some instances within $1 \mathrm{~h}$, in $\mathrm{C} 3 \mathrm{H} / \mathrm{HeN}$ mice primed with muramyl dipeptide (MDP). They also induced serum cytokines in the surviving mice. The present study investigated the structural components responsible for these activities. Teichuronic acids, a component of M. luteus cell walls, induced tumour necrosis factor- $\alpha$ (TNF- $\alpha$ ) and interleukin-6 (IL-6) in MDP-primed $\mathrm{C} 3 \mathrm{H} / \mathrm{HeN}$ mice. Peptidoglycans had little effect on the cytokine-inducing activities. Reducing teichuronic acids, i.e., teichuronic acids whose carboxyl groups had been reduced, lost their cytokine-inducing activities. Neither peptidoglycans nor teichuronic acids induced anaphylactoid reactions in the MDP-primed mice. Purified teichuronic acids also induced TNF- $\alpha$ and IL-6 production in $\mathrm{C} 3 \mathrm{H} / \mathrm{HeN}$ murine peritoneal macrophages and human whole-blood cells in the culture, but reduced teichuronic acids did not. The purified teichuronic acids induced no TNF- $\alpha$ and only low levels of IL-6 in MDP-primed $\mathrm{C} 3 \mathrm{H} / \mathrm{HeJ}$ mice, and neither cytokine in peritoneal macrophage cultures from $\mathrm{C} 3 \mathrm{H} / \mathrm{HeJ}$ mice with a single point of mutation in Toll-like receptor 4 (TLR4) gene. These findings suggest that induction of cytokines by teichuronic acids is mainly TLR4-dependent.
\end{abstract}

\section{Introduction}

Micrococcus luteus (lysodeikticus) was initially isolated from blood-agar cultures of the nasal secretions of a patient with acute coryza [1]. Human skin is now considered to be a primary habitat of this bacterium and it has also been detected in the mucous membranes, including the buccal cavity, as well as in water and soil [2]. Although M. luteus is usually disregarded as a contaminant in clinical specimens, it has been implicated in bacteraemia [3], septic shock [4], septic arthritis [5], endocarditis [6-8], meningitis [9], intracranial suppuration [10] and pneumonia [11].

Received 6 March 2000; revised version accepted 26 May 2000.

Corresponding author: Professor H. Takada (email: dent-ht@ mail.cc.tohoku.ac.jp).

Present address: Department of Dental Radiology, Kagoshima University Dental School, Kagoshima 890-8544, Japan.
A previous study [12] showed that M. luteus cells and cell walls caused anaphylactoid reactions leading to death, in some instances within $1 \mathrm{~h}$, in $\mathrm{C} 3 \mathrm{H} / \mathrm{HeN}$ mice primed with $\mathrm{N}$-acetylmuramyl-L-alanyl-D-isoglutamine (muramyl dipeptide; MDP). It also demonstrated that the cells and cell walls induced tumour necrosis factor (TNF) and interleukin-6 (IL-6) in the serum of the surviving mice. M. luteus cell walls consist of two polymers, peptidoglycans $[13,14]$ and teichuronic acids [15-17], covalently bonded to each other. Peptidoglycans are generally known to be potent immunostimulants and to induce various cytokines in vivo and in vitro [18]. However, the immunoadjuvant activities of peptidoglycans of $M$. luteus in guinea-pigs were reported to be weak compared with those of other bacterial peptidoglycans $[19,20]$. It was also reported that bacterial peptidoglycans showed low cytokineinducing activities in murine macrophage culture [21]. The immunomodulating activities of teichuronic acids have not been studied.

The present study investigated which components of 
the cell walls could cause anaphylactoid reactions or induced cytokines such as TNF and IL-6 in MDPprimed $\mathrm{C} 3 \mathrm{H} / \mathrm{HeN}$ mice.

\section{Materials and methods}

\section{Bacterial strains}

M. luteus strains IFO 3333, MT and NCTC 2665 were mainly used. Strain IFO 3333 was supplied by the Institute for Fermentation, Osaka, Japan. Strain MT is an autolysis-defective, tetrad-forming mutant derived from strain IFO 3333, and MT/T is not a strain but cell packets formed from MT cells by treatment with proteases [22]. Strains NCTC 2665, also a type strain supplied by the National Collection of Type Cultures, Colindale Avenue, London, is autolysis-defective [23].

\section{Peptidoglycans and glycans}

Cell walls were prepared as described previously [23] from log-phase cells (LC) and stationary phase cells (SC), and they were designated as LCW and SCW, respectively. Peptidoglycans were prepared from cell walls as described previously [24]. LCW and SCW were subjected to mild acid treatment $(0.1 \mathrm{~N} \mathrm{HC} 1$, $100^{\circ} \mathrm{C}, 10 \mathrm{~min}$ ) and centrifuged at $30000 \mathrm{~g}$ for $30 \mathrm{~min}$. The precipitate consisting of peptidoglycans was designated as PG (LCW) and PG (SCW), respectively. The mild acid treatment of the cell walls greatly decreased the teichuronic acid content of the cell walls [25-27]. The glycans were prepared from whole cells as described previously [28]. Stationary-phase cells of strain NCTC 2665 were refluxed with hydrazine hydrate $100 \%$ for $5 \mathrm{~h}$ or $20 \mathrm{~h}$. The resulting samples were $\mathrm{N}$-reacetylated and designated as G 5 (NCTC 2665) and G 20 (NCTC 2665), respectively. G 5 (NCTC 2665) and G 20 (NCTC 2665) are polymers mainly composed of $\mathrm{N}$-acetyl muramic acid and $\mathrm{N}$-acetyl glucosamine residues, but the former residues are partly destroyed, to a greater extent in G 20 (NCTC 2665) than in G 5 (NCTC 2665). G 5 (NCTC 2665) has a few amino acids which are components of peptidoglycans and G 20 (NCTC 2665) has practically no amino acids.

\section{Teichuronic acids}

Teichuronic acids were prepared from cells as described previously [24]. LCW and SCW were digested with lysozyme (Lysozyme from chicken egg-white, $3 \times$ crystallised, dialysed and lyophilised; Sigma) in $0.1 \mathrm{M}$ sodium acetate buffer, $\mathrm{pH} 6.0$, at $37^{\circ} \mathrm{C}$ for $20 \mathrm{~h}$ and dialysed against distilled water. The dialysate was designated as TUA (LCW) and TUA (SCW).

\section{Purified teichuronic acids (p-TUA) and reduced teichuronic acids (p-TUA-[H])}

p-TUA and p-TUA-[H] were prepared as described previously [15]. Briefly, cell walls prepared from SC
(NCTC 2665), i.e., SCW (NCTC 2665) were digested with egg-white lysozyme and further with $\mathrm{L}_{11}$ enzyme. The digest was dialysed against distilled water and fractionated by an ECTEOLA-cellulose column. The fractionated sample was designated p-TUA. To convert the aminohexuronic acid residues of p-TUA to aminohexose residues, p-TUA were acetylated with acetic anhydride, reduced with diborane and treated with mild alkali $(0.01 \mathrm{~N} \mathrm{NaOH}$, at room temperature, overnight) to remove $O$-acetyl groups, and the sample thus obtained was designated as p-TUA- $[\mathrm{H}]$. The reduction of the carboxyl groups of the aminohexuronic acid residues to alcohol was confirmed by comparison of the infrared spectrum of p-TUA with that of p-TUA$[\mathrm{H}]$. The chemical structures of p-TUA and p-TUA-[H] are shown below $[15,16]$.

$$
\begin{aligned}
& -\left[\text {-D-ManNAcUA } \frac{\beta-1,6}{\operatorname{D}} \mathrm{D}-\mathrm{Glc} \frac{\alpha-1,4}{\mathrm{n}}\right]_{\mathrm{n}}-\mathrm{p} \text {-TUA } \\
& -\left[\text {-D-ManNAc } \frac{\beta-1,6}{\mathrm{D}} \mathrm{D}-\mathrm{Glc} \frac{\alpha-1,4}{\mathrm{n}}\right]_{\mathrm{n}}-\mathrm{p}-\mathrm{TUA}-[\mathrm{H}]
\end{aligned}
$$

The lipopolysaccharide(LPS)-like content in PG (NCTC 2665, SCW), TUA (NCTC 2665, SCW), p-TUA and p-TUA-[H] was $0.151 \mathrm{ng} / \mathrm{mg}, 0.226 \mathrm{ng} / \mathrm{mg}$, $0.091 \mathrm{ng} / \mathrm{mg}$ and $0.070 \mathrm{ng} / \mathrm{mg}$, respectively, based on the results of the colorimetric Limulus test with Escherichia coli O111:B4 LPS as a control in an Endospecy Test (Seikagaku Kogyo, Tokyo, Japan) [29].

\section{Chemical treatment of whole cells}

Whole cells such as LC (IFO 3333) were subjected to mild acid treatment and mild Smith degradation [30], and the resulting samples were designated as, e.g., Mild Acid LC (IFO 3333) and Mild Smith LC (IFO 3333). These treatments greatly decreased the content of teichuronic acids in the cell walls and whole cells [25-27].

All the materials described above were lyophilised and used as test specimens.

\section{Other reagents}

MDP was supplied by Daiichi Pharmaceutical (Tokyo, Japan). Purified LPS prepared from Salmonella choleraesuis subsp. choleraesuis serotype abortus equi (S. abortus-equi) was supplied by C. Galanos (Max-PlankInstitut für Immunbiologie, Freiburg, Germany) [31]. Poly-L-lysine hydrobromide (MW 30000-70 000) and poly-L-glutamic acid sodium salt (MW 15000-50 000) were purchased from Sigma.

\section{Induction of anaphylactoid reaction and serum cytokines in mice}

The experimental method was described previously [12]. Briefly, groups of three-to-six $\mathrm{C} 3 \mathrm{H} / \mathrm{HeN}$ or $\mathrm{C} 3 \mathrm{H} / \mathrm{HeJ}$ mice (6-12-week-old males and females) were primed with an intravenous (i.v.) injection of 
MDP (100 $\mu \mathrm{g}$ in $0.2 \mathrm{ml}$ of pyrogen-free physiological saline). Then $4 \mathrm{~h}$ later, the mice received an i.v. injection of test specimen dissolved or homogeneously suspended in $0.2 \mathrm{ml}$ of saline, and were observed for $1 \mathrm{~h}$ to determine the incidence of anaphylactoid reaction and death. At $90 \mathrm{~min}$ after the injection of the test specimen, surviving mice were bled from the subaxillary vein under ether anaesthesia to obtain test sera. All protocols used in this study were approved by the Animal Research Committee of Kagoshima University Dental School.

\section{Induction of cytokines in murine pertioneal macrophage cultures}

The experimental method was described previously [32]. Briefly, thioglycolate medium-induced peritoneal macrophages $\left(10^{5} / 100 \mu \mathrm{l} /\right.$ well of a flat-bottomed microculture plate) from $\mathrm{C} 3 \mathrm{H} / \mathrm{HeN}$ or $\mathrm{C} 3 \mathrm{H} / \mathrm{HeJ}$ mice were cultured in RMPI 1640 medium with or without test specimens at $37^{\circ} \mathrm{C}$ for $24 \mathrm{~h}$. The cytokine activities of the culture supernate were measured as described below.

\section{Induction of cytokines in human peripheral whole-blood cell cultures}

The experimental method was described previously [32]. Briefly, heparinised peripheral blood was obtained from a healthy adult volunteer after informed consent. The blood $(25 \mu \mathrm{l})$ was directly (without fractionation) incubated with test specimens in RPMI 1640 medium $(100 \mu \mathrm{l})$ at $37^{\circ} \mathrm{C}$ for $24 \mathrm{~h}$. Triplicate culture supernates were assayed for cytokines.

\section{Measurement of cytokines}

The TNF- $\alpha$ and IL-6 activities in the murine serum and murine macrophage and human whole-blood culture supernates were measured by enzyme-linked immunosorbant assay (ELISA) kits for murine and human TNF- $\alpha$ and IL-6 (Biosource International, Camirillo, CA, USA).

\section{Results}

Activities of peptidoglycans and glycans in MDPprimed $\mathrm{C} 3 \mathrm{H} / \mathrm{HeN}$ mice

Cell walls from strain NCTC 2665 as reference materials induced anaphylactoid reactions and early death within $1 \mathrm{~h}$ at incidences of $100 \%$ and $100 \%$ at a dose of $500 \mu \mathrm{g}$, and $33 \%$ and $0 \%$ at a dose of $100 \mu \mathrm{g}$, respectively. Other materials including peptidoglycans and glycans failed to induce anaphylactoid reactions in MDP-primed $\mathrm{C} 3 \mathrm{H} / \mathrm{HeN}$ mice. As shown in Fig. 1, peptidoglycans prepared from the stationary-phase cells of strains NCTC 2665, at a dose of $500 \mu \mathrm{g}$, induced low levels of TNF- $\alpha$ in mice, but other peptidoglycans and glycans did not. Peptidoglycans induced low levels of IL-6 at a dose of $500 \mu \mathrm{g}$, and the glycan preparations showed practically no activity. It should be noted that MDP alone induced neither anaphylactoid reactions nor serum cytokines in $\mathrm{C} 3 \mathrm{H} / \mathrm{HeN}$ mice even at a dose of $5 \mathrm{mg}$.

\section{Cytokine-inducing activities of teichuronic acids in MDP-primed $\mathrm{C} 3 \mathrm{H} / \mathrm{HeN}$ mice}

The teichuronic acid preparation failed to induce an anaphylactoid reaction in the MDP-primed $\mathrm{C} 3 \mathrm{H} / \mathrm{HeN}$ mice (Fig. 1). Among the teichuronic acid preparations, those prepared from strains B 361 and NCTC 2665 induced both serum TNF- $\alpha$ and IL- 6 in MDP-primed $\mathrm{C} 3 \mathrm{H} / \mathrm{HeN}$ mice. It should be noted that other inactive or low activity teichuronic acid preparations in Fig. 1 were derived from cell-wall preparations lacking cytokine-inducing activities [12]. The cytokine-inducing activities of the teichuronic acids derived from strain NCTC 2665 were maintained after purification (p-TUA). In contrast, reduced teichuronic acids (p-TUA-[H]) induced neither TNF- $\alpha$ nor IL-6. When p-TUA $(100 \mu \mathrm{g})$ was injected into non-primed $\mathrm{C} 3 \mathrm{H} / \mathrm{HeN}$ mice, practically no TNF- $\alpha$ and only low levels of IL-6 were detected.

\section{Effect of chemical treatments of whole cells on activities in MDP-primed $\mathrm{C} 3 \mathrm{H} / \mathrm{HeN}$ mice}

Whole cells subjected to mild acid treatment and mild Smith degradation induced anaphlylactoid reactions, but they induced no TNF- $\alpha$ and little IL-6 (Fig. 2).

Cytokine-inducing activities of mixtures of teichuronic acids and peptidoglycans or glycans in MDP-primed $\mathrm{C} 3 \mathrm{H} / \mathrm{HeN}$ mice

As shown in Fig. 1, the mixture of p-TUA and PG (NCTC 2665, SCW) or G5 (NCTC 2665) or G20 (NCTC 2665) showed cytokine-inducing activities that were significantly lower than those of p-TUA alone in the serum of MDP-primed $\mathrm{C} 3 \mathrm{H} / \mathrm{HeN}$ mice. The mixture of teichuronic acids and peptidoglycans or glycans did not cause anaphylactoid reactions and death in mice.

Effect of addition of poly-L-lysine and poly-Lglutamic acid and MDP on cytokine-inducing activities of teichuronic acids in MDP-primed $\mathrm{C} 3 \mathrm{H} / \mathrm{HeN}$ mice

The mixture of poly-L-lysine and p-TUA, which is slightly turbid, induced less TNF- $\alpha$ and IL-6 than p-TUA alone in mice. In contrast, the mixtures of polyL-glutamic acid or MDP and p-TUA induced significantly less TNF- $\alpha$ than p-TUA alone and significantly more IL-6 than p-TUA alone in mice. (Fig. 3). 
Peptidoglycans

PG (IFO 3333, LCW)
PG (IFO 3333, SCW)
PG (MT, LCW)
PG (MT/T, LCW)
PG (NCTC 2665 SCW)

Glycans

G 5 (NCTC 2665)

G 20 (NCTC 2665)

Teichuronic acids

TUA (B 361, SCW)

TUA (IFO 3333, LCW)

TUA (IFO 3333, SCW)

TUA (MT, LCW)

TUA (MT/T, LCW)

TUA (NCTC 2665, SCW)

p-TUA

p-TUA-[H]

Teichuronic acids

+ Peptidoglycans or Glycans

p-TUA

+ PG (NCTC 2665, SCW)

p-TUA

+ G 5 (NCTC 2665)

P-TUA

+ G 20 (NCTC 2665)

Reference materials

SCW (NCTC 2665)

LPS

Saline $\mu \mathrm{g}$

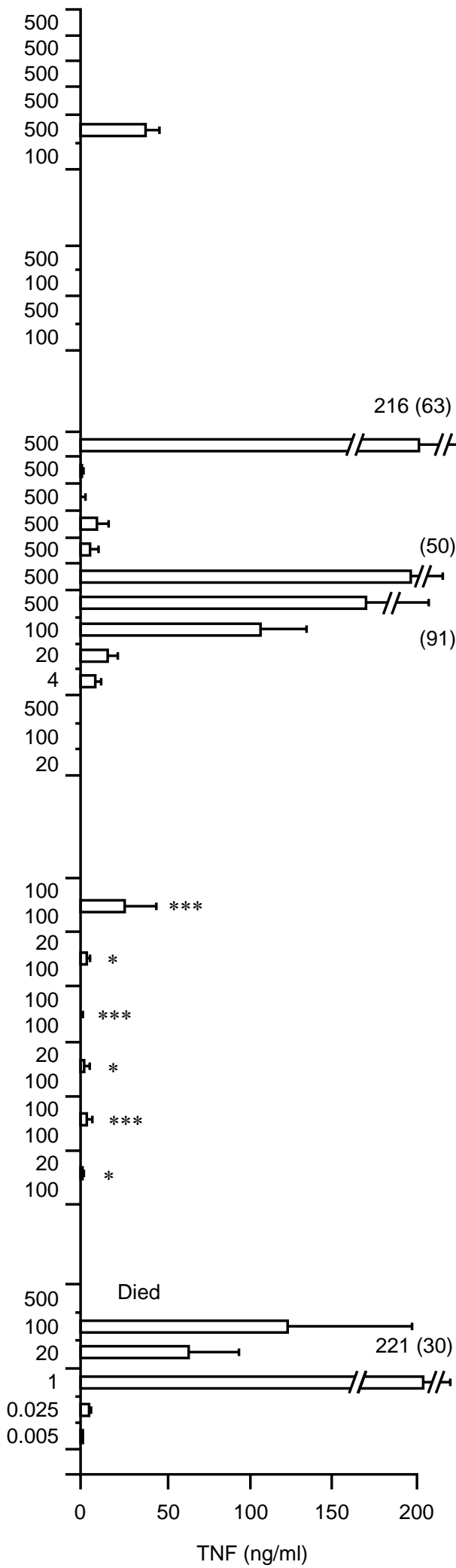

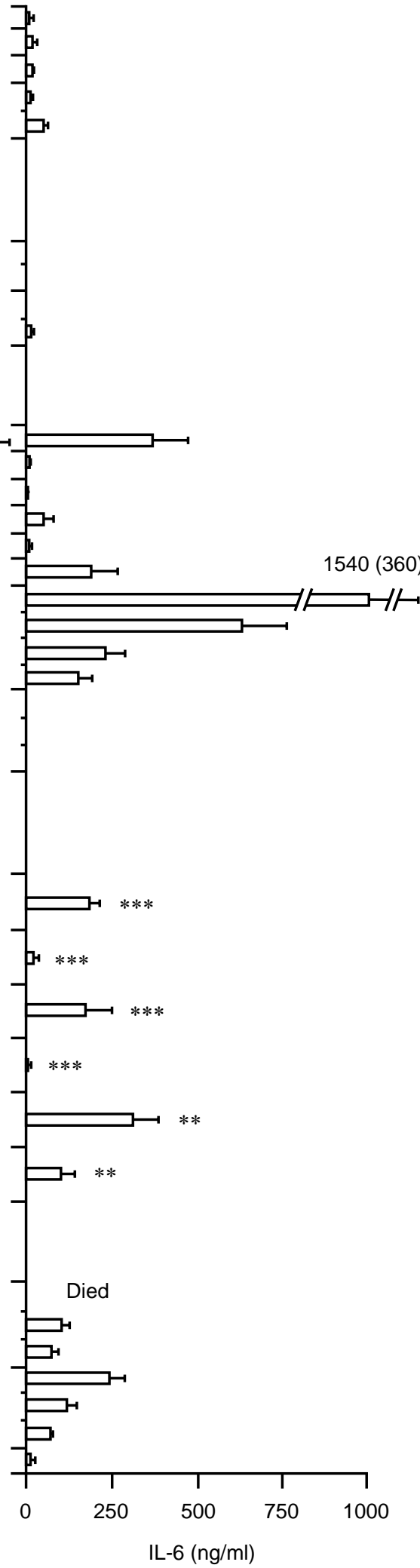

Fig. 1. Induction of serum cytokines by peptidoglycans, glycans, teichuronic acids and their mixtures in MDP-primed $\mathrm{C} 3 \mathrm{H} / \mathrm{HeN}$ mice. Groups of three-to-six $\mathrm{C} 3 \mathrm{H} / \mathrm{HeN}$ mice were primed with an i.v. injection of MDP $(100 \mu \mathrm{g})$. Then $4 \mathrm{~h}$ later, the mice received an intravenous injection of test specimen and they were observed for $1 \mathrm{~h}$ to record the incidence of anaphylactoid reaction and death. At $90 \mathrm{~min}$ after the injection of the test specimen, surviving mice were bled to obtain test sera. The serum TNF- $\alpha$ and IL- 6 levels were measured by ELISA and their values are expressed as means and SEM (left and right columns, respectively). 'Died' means that all the mice in the group died within $1 \mathrm{~h}$ after the injection of the test material. 'Teichuronic acids + Peptidoglycans or Glycans' were examined by Student's $t$ test, indicating significant difference from the respective ' $\mathrm{p}$-TUA' $\left({ }^{*} \mathrm{p}<0.05,{ }^{* *} \mathrm{p}<0.01,{ }^{* * *} \mathrm{p}<0.001\right)$. 
Whole Cells

Mild Acid LC (IFO 3333)

Mild Smith LC (IFO 3333)

Mild Acid LC (MT)

Mild Smith LC (MT)

Mild Acid LC (MT/T)

Mild Smith LC (MT/T)

Mild Acid SC (NCTC 2665)

Mild Smith SC (NCTC 2665)

Reference materials

SC (NCTC 2665)

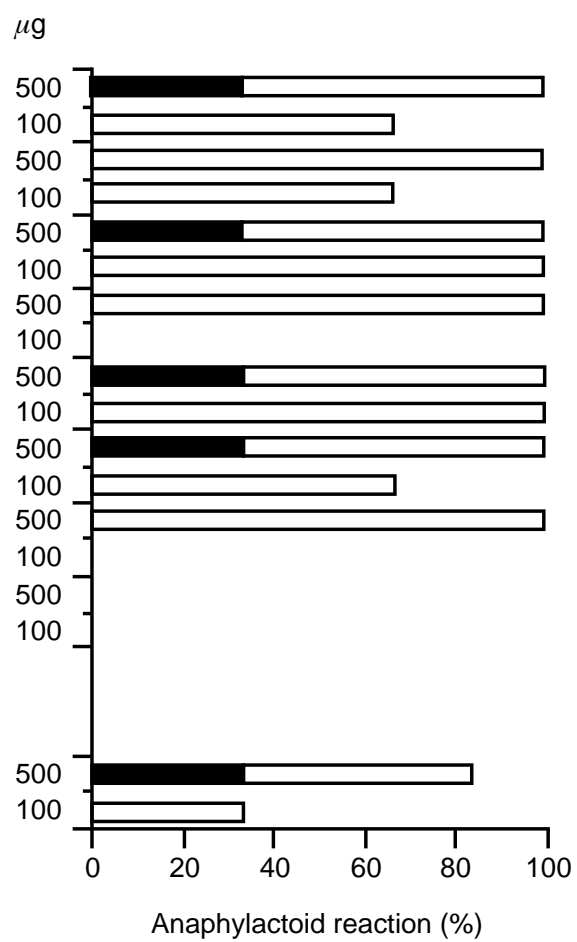

Fig. 2. Induction of anaphylactoid reactions in $\mathrm{MDP}$-primed $\mathrm{C} 3 \mathrm{H} / \mathrm{HeN}$ mice by whole cells treated with reagents. Procedures were the same as those described in Fig. 1. The incidences of anaphylactoid reaction $(\square)$ and death $(\square)$ are shown. No TNF- $\alpha$ and little IL-6 activity was induced by these cells in the sera of the mice.

Mixed materials

p-TUA

+ poly-L-lysine

p-TUA

+ poly-L-glutamic acid

p-TUA

+ MDP

\section{Reference materials}

p-TUA

poly-L-lysine

poly L-glutamic acid MDP
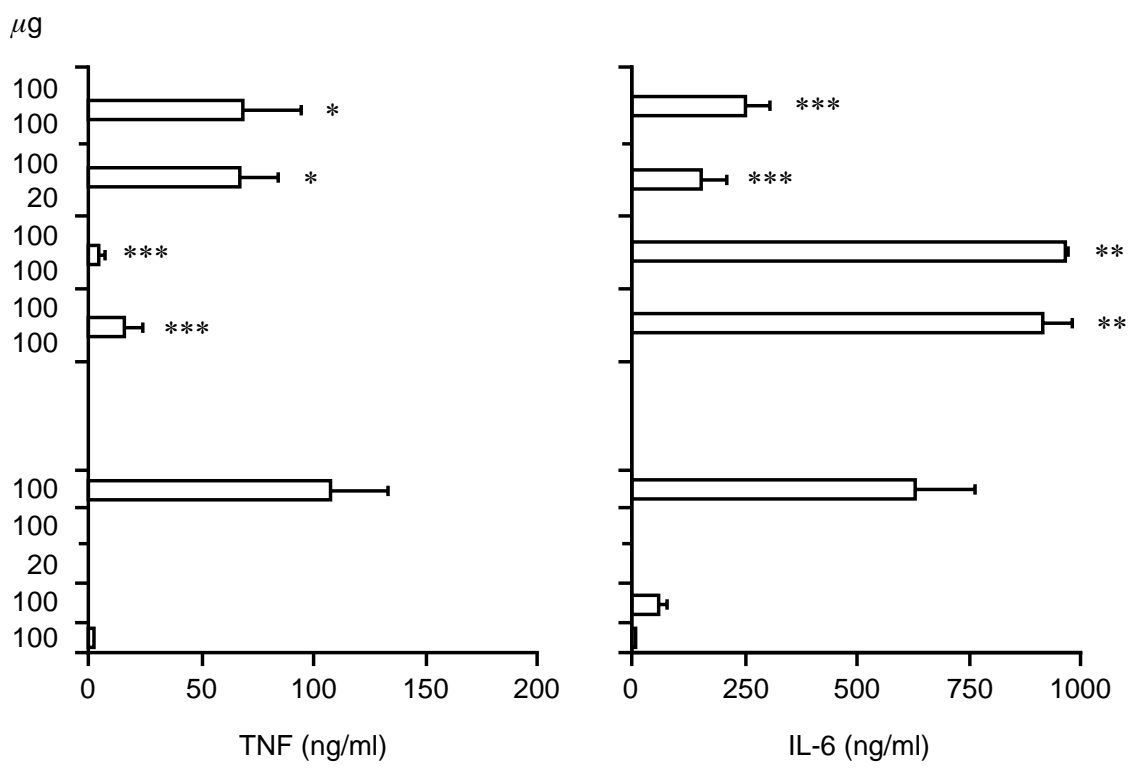

Fig. 3. Effects of addition of poly-L-lysine, poly-L-glutamic acid and MDP on cytokine-inducing activities of teichuronic acids in MDP-primed $\mathrm{C} 3 \mathrm{H} / \mathrm{HeN}$ mice. Procedures were the same as those described in Fig. 1. At a dose of $100 \mu \mathrm{g}$ of poly-L-lysine alone, one of three MDP-primed $\mathrm{C} 3 \mathrm{H} / \mathrm{HeN}$ mice had an anaphylactoid reaction and died. The injection of $500 \mu \mathrm{g}$ of poly-L-lysine alone or of the mixture of $500 \mu \mathrm{g}$ of poly-L-lysine and $100 \mu \mathrm{g}$ of p-TUA caused anaphylactoid reactions and death in all three mice. 'Mixed materials' were examined by Student's $t$ test, indicating significant difference from the respective 'p-TUA' $\left.{ }^{*} \mathrm{p}<0.05,{ }^{* *} \mathrm{p}<0.01,{ }^{* * *} \mathrm{p}<0.001\right)$. 
Cytokine-inducing activities of teichuronic acids in peritoneal macrophage cultures from $\mathrm{C} 3 \mathrm{H} / \mathrm{HeN}$ mice

p-TUA induced TNF- $\alpha$ and IL-6 in peritoneal macrophage cultures from $\mathrm{C} 3 \mathrm{H} / \mathrm{HeN}$ mice (Fig. 4). In contrast, p-TUA-[H] was scarcely active in this respect.

\section{Cytokine-inducing activities of teichuronic acids in $\mathrm{C} 3 \mathrm{H} / \mathrm{HeJ}$ mice}

p-TUA and p-TUA-[H] failed to induce anaphylactoid reactions in MDP-primed $\mathrm{C} 3 \mathrm{H} / \mathrm{HeJ}$ mice as well as in MDP-primed $\mathrm{C} 3 \mathrm{H} / \mathrm{HeN}$ mice. In contrast to the high cytokine-inducing activities of p-TUA in MDP-primed $\mathrm{C} 3 \mathrm{H} / \mathrm{HeN}$ mice (Fig. 1), in MDP-primed $\mathrm{C} 3 \mathrm{H} / \mathrm{HeN}$ mice the cytokine-inducing activities of p-TUA were weak; no TNF- $\alpha$ - and only low IL-6-inducing activities were shown. p-TUA- $[\mathrm{H}]$ induced practically no cytokines in this respect (Fig. 5). Furthermore, p-TUA and p-TUA- $[\mathrm{H}]$ showed no TNF- $\alpha$ - or IL-6-inducing activities in peritoneal macrophage cultures from $\mathrm{C} 3 \mathrm{H} / \mathrm{HeJ}$ mice.

\section{Cytokine-inducing activities of teichuronic acids in human whole-blood cultures}

p-TUA induced TNF- $\alpha$ and IL-6 in human whole-blood cultures, but p-TUA-[H] did not (Fig. 6).

\section{Discussion}

This is the first report to demonstrate that teichuronic acids from $M$. luteus induced inflammatory cytokines, TNF- $\alpha$ and IL-6, in vivo and in vitro. Whole bacterial cells subjected to mild acid treatment and mild Smith degradation to remove teichuronic acids induced no TNF- $\alpha$ and little IL-6 in MDP-primed $\mathrm{C} 3 \mathrm{H} / \mathrm{HeN}$ mice. Whole cells lacking teichuronic acids (strains AH-47 and AH-149) induced no TNF- $\alpha$ and little IL-6 [12]. These findings support the concept that teichuronic acids are responsible for the cytokine induction.

Peptidoglycans showed no immunostimulatory activities in murine macrophage cultures [21], and those of $M$. luteus were reported to show only weak immunoadjuvant activity in guinea-pigs as compared with other bacterial peptidoglycans $[19,20]$. In the present study, no induction of anaphylactoid reactions was observed in MDP-primed and peptidoglycan-challenged $\mathrm{C} 3 \mathrm{H} / \mathrm{HeN}$ mice and little or no TNF- $\alpha$ or IL-6 was detected in the serum of the mice. It was shown by Raman laser spectroscopy that peptidoglycans from IFO 3333 monococcal cells, MT tetrad cells and MT/T packet cells differed in the conformation of their glycan chains [33]. However, no difference was observed in their ability to induce anaphylactoid reactions and serum cytokines in MDP-primed $\mathrm{C} 3 \mathrm{H} / \mathrm{HeN}$ mice in the present study.

Teichuronic acids are polymers in which $\mathrm{N}$-acetylmannosaminuronic acid and glucose residues are alternatively linked (see Materials and methods, p-TUA). The ability of the teichuronic acid preparations to induce cytokines in MDP-primed $\mathrm{C} 3 \mathrm{H} / \mathrm{HeN}$ mice varied with the bacterial strains from which they had been prepared. The reason why TUA (B 361, SCW), TUA (NCTC 2665, SCW) and p-TUA, i.e., teichuronic acids from the strains B 361 and NCTC 2665 had stronger cytokine-inducing ability than TUA from other cells is not known. It should be noted that the teichuronic acids
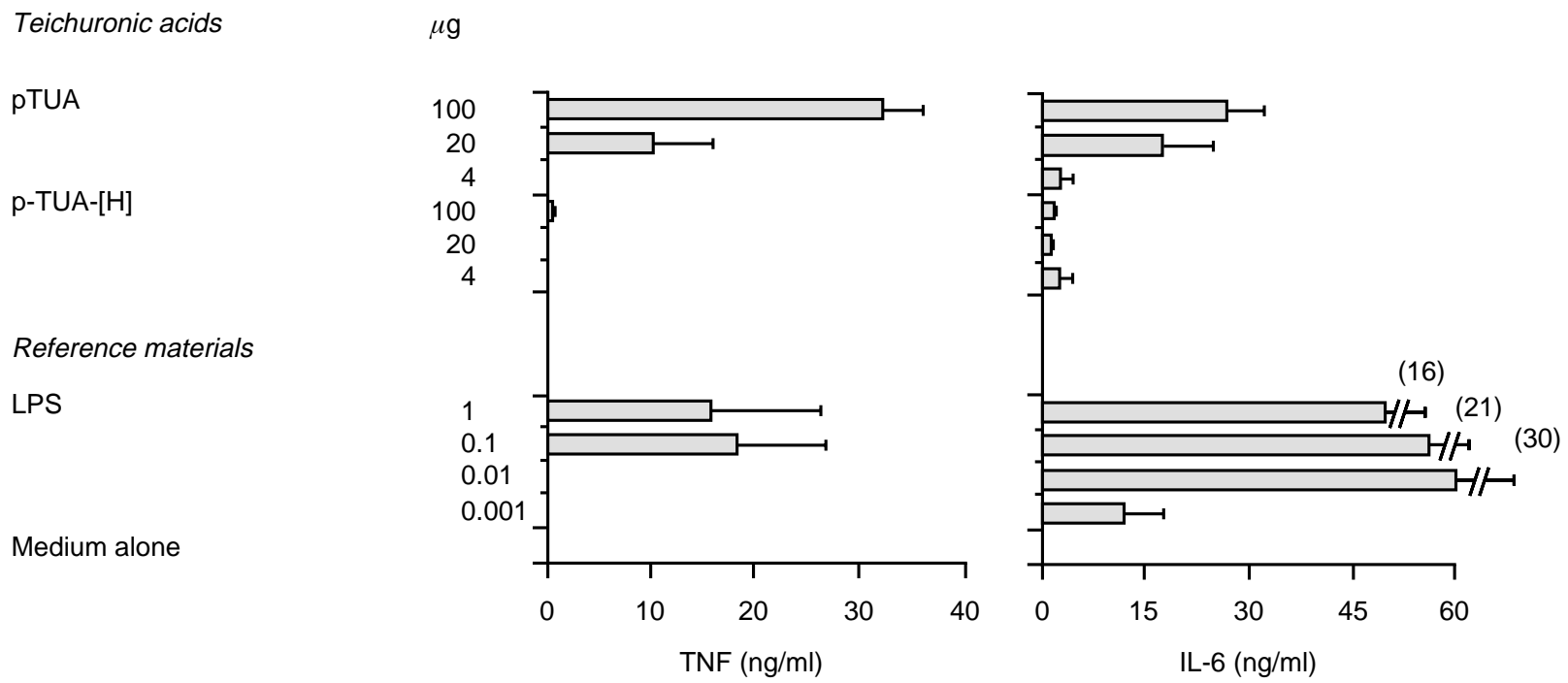

Fig. 4. Induction of cytokines by teichuronic acids in peritoneal macrophage cultures from $\mathrm{C} 3 \mathrm{H} / \mathrm{HeN} \mathrm{mice}$. Thioglycollate medium-induced peritoneal macrophages $\left(10^{5} / 100 \mu \mathrm{l} /\right.$ well of a flat-bottomed microculture plate) of $\mathrm{C} 3 \mathrm{H} / \mathrm{HeN}$ mice were cultured in RPMI 1640 medium with or without test materials at $37^{\circ} \mathrm{C}$ for $24 \mathrm{~h}$. The TNF- $\alpha$ and IL-6 activities of the culture supernate are shown in the left and right columns, respectively. The concentrations of samples are $\mu \mathrm{g} / \mathrm{ml}$. 

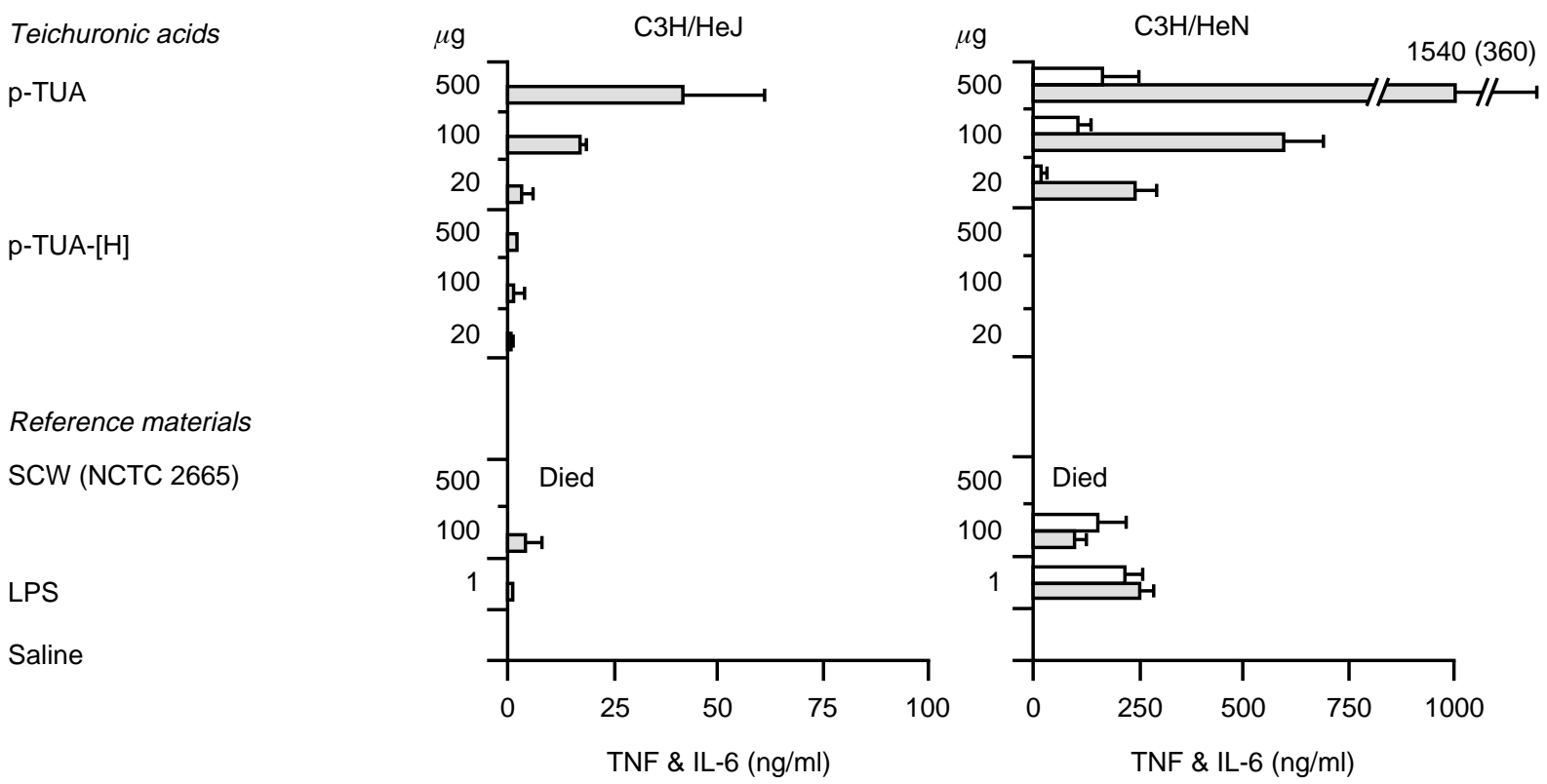

Fig. 5. Near failure of teichuronic acids to induce cytokines in MDP-primed $\mathrm{C} 3 \mathrm{H} / \mathrm{HeJ}$ mice. Procedures were the same as those described in Fig. 1, except for the use of $\mathrm{C} 3 \mathrm{H} / \mathrm{HeJ}$ mice instead of $\mathrm{C} 3 \mathrm{H} / \mathrm{HeN}$ mice. TNF- $\alpha$ level is shown in upper bars and IL-6 level in lower bars, in MDP-primed $\mathrm{C} 3 \mathrm{H} / \mathrm{HeJ}$ mice (left column) and in MDP-primed $\mathrm{C} 3 \mathrm{H} / \mathrm{HeN}$ mice (right column; for comparison, data in Fig. 1 are reprinted). In MDP-primed $\mathrm{C} 3 \mathrm{H} / \mathrm{HeJ}$ mice only low IL-6 level was detected as shown in left column.
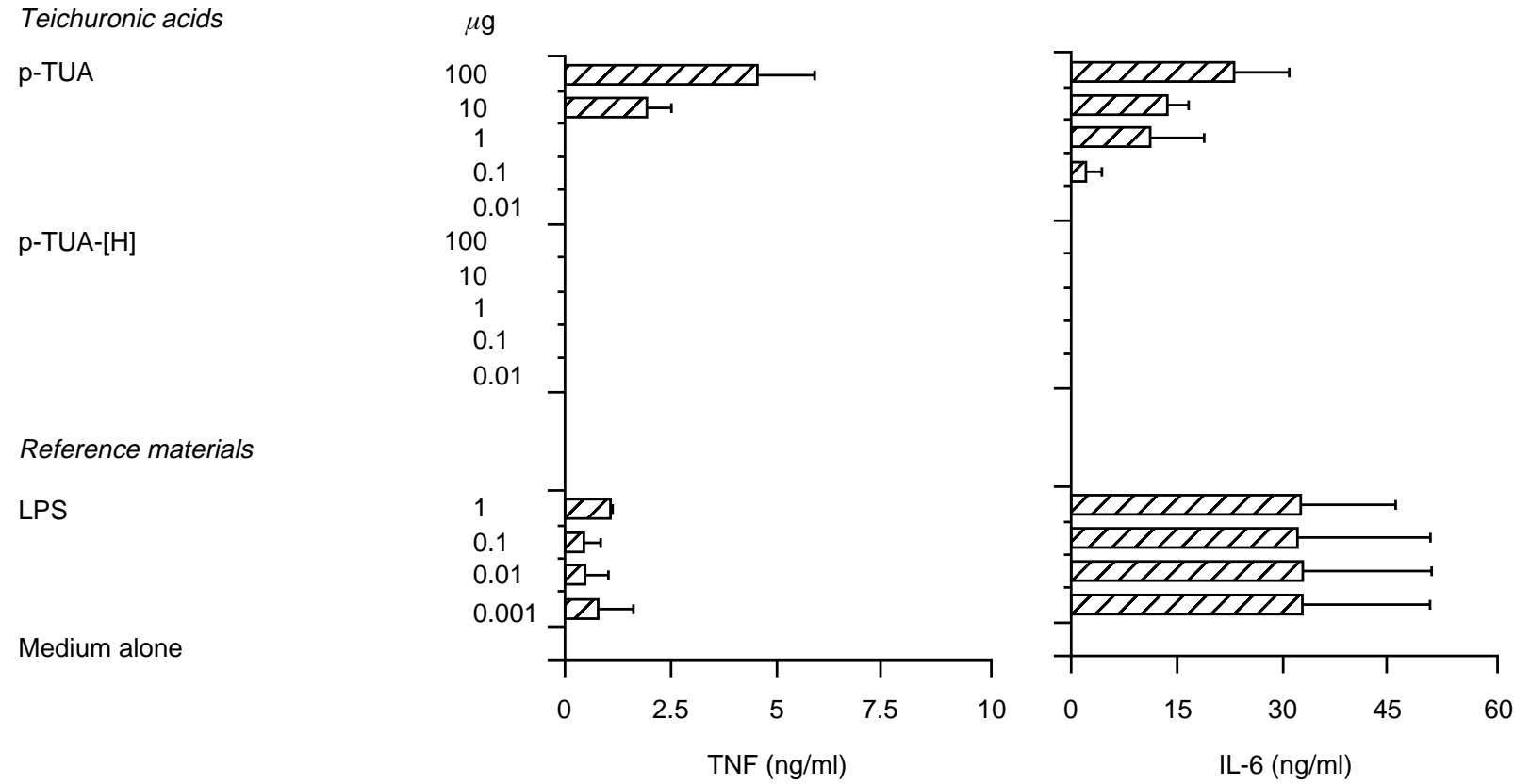

Fig. 6. Induction of cytokines by teichuronic acids in human whole-blood cultures. Heparinised peripheral blood ( $25 \mu 1)$ was directly (without fractionation) incubated with test materials at the indicated doses in RPMI 1640 medium (100 $\mu$ ) at $37^{\circ} \mathrm{C}$ for $24 \mathrm{~h}$. The TNF- $\alpha$ and IL-6 levels in the culture supernate are shown in the left and right columns, respectively. The concentrations of samples are $\mu \mathrm{g} / \mathrm{ml}$.

prepared from cell walls lacking cytokine-inducing activities in the previous study [12] had practically no cytokine-inducing activities. Furthermore, IFO 3333, MT, MT/T and NCTC 2665 cells aggregated with the antiserum containing anti-teichuronic acid antibody [34], and mild acid treatment of these cells decreased their agglutinability with the serum. Cell walls from these strains contain hexose corresponding to glucose of teichuronic acids, and mild acid treatment of these cell walls decreased the hexose content [25-27]. Teichuronic acids from B 361, IFO 3333, MT, MT/T and NCTC 2665 cells gave precipitin lines which fused with the line of p-TUA in an immunodiffusion experiment (unpublished data). The presence of three 
kinds of chemical structures for the linkage region of teichuronic acids and peptidoglycans is suggested [3538]. Although there is no evidence available, a fine or additional structure besides the main backbone consisting of a $\mathrm{N}$-acetylmannosaminuronic acid and glucose may be different among these teichuronic acids.

Reduced teichuronic acids, polymers in which $N$ acetylmannosamine and glucose residues are alternately linked (see Materials and methods, p-TUA- $[\mathrm{H}]$ ), did not induce cytokines. This may indicate that the carboxyl groups of the $\mathrm{N}$-acetylmannosaminuronic acid residues play an important role in the induction of cytokines. Therefore, the effect of the addition of polyL-lysine and poly-L-glutamic acid on the ability of teichuronic acids to induce cytokines in MDP-primed $\mathrm{C} 3 \mathrm{H} / \mathrm{HeN}$ mice was examined. Poly-L-lysine showed an inhibitory effect of p-TUA on cytokine-inducing activities, presumably due to an electrostatic interaction between positively charged amino groups of poly-Llysine and negatively charged carboxyl groups of p-TUA, or the cytotoxic effect of poly-L-lysine, or both $[39,40]$. Peptidoglycans, glycans, poly-L-glutamic acid and MDP suppressed the TNF- $\alpha$ induction by $p$-TUA, probably due to the competitive inhibition by their carboxyl groups on those of p-TUA. Although peptidoglycans and glycans significantly inhibited the IL-6 induction by p-TUA, poly-L-glutamic acid and MDP enhanced the IL-6 induction by p-TUA. Further study is necessary to elucidate the suppression of TNF- $\alpha$ inducing activity and the enhancement of IL-6-inducing activity of p-TUA by poly-L-glutamic acid and MDP.

It is well known that $\mathrm{C} 3 \mathrm{H} / \mathrm{HeJ}$ mice are resistant to LPS. Recently, a genetic reason for the unresponsiveness of these mice to LPS was revealed; $\mathrm{C} 3 \mathrm{H} / \mathrm{HeJ}$ mice have a point mutation in Toll-like receptor 4 (TLR4) [41-43]. As expected, TLR4-deficient $\left(\mathrm{TLR}^{-/-}\right.$) mice did not respond to LPS [41]. In this context, a recent study by Takeuchi et al. [44] showed that purified lipoteichoic acids (LTA) from Staphylococcus aureus and Streptococcus sanguis induced TNF- $\alpha$ and IL-6 in peritoneal macrophage cultures from $\mathrm{TLR}^{+/+}$but not $\mathrm{TLR}^{-/-}$mice. LTA are the amphiphilic materials associated with the cytoplasmic membrane of most gram-positive bacteria except $M$. luteus $[45,46]$. In this study, the cytokine-inducing activities of p-TUA, which is almost free from LPS, exhibited little or no activity both in in vivo and in vitro in $\mathrm{C} 3 \mathrm{H} / \mathrm{HeJ}$ mice. These findings suggest that not only LPS but also other bacterial cell surface components are recognised by TLR4 to activate the innate immunity system.

p-TUA also induced TNF- $\alpha$ and IL-6 in human peripheral blood cultures. The present study has shown that the teichuronic acid moiety was the only active component of $M$. luteus cell walls capable of inducing inflammatory cytokines in vivo and in vitro. Therefore, teichuronic acids might be responsible for the inflam- matory diseases induced by $M$. luteus. However, teichuronic acids did not induce anaphylactoid reactions in the MDP-primed $\mathrm{C} 3 \mathrm{H} / \mathrm{HeN}$ mice, whereas whole cells containing low levels of teichuronic acids following treatment and whole cells lacking teichuronic acids (mutant strains AH-47 and AH-149) did [12]. Also, peptidoglycans did not induce anaphylactoid reactions in MDP-primed $\mathrm{C} 3 \mathrm{H} / \mathrm{HeN}$ mice. A recent study by Shibazaki et al. [47] revealed that complement activation followed by platelet degradation is involved in anaphylactoid reactions induced by LPS. These findings suggest that $M$. luteus cell surface materials other than teichuronic acids and peptidoglycans, which powerfully activate the complement system, might induce anaphylactoid reactions. In this context, poly-L-lysine, which induced an anaphylactoid reaction (Fig. 3), activates the complement system via C-reactive protein [48].

We thank Dr C. Galanos (Max-Plank-Institut für Immunobiologie, Freiburg, Germany) for kindly supplying purified LPS from $S$. abortus equi. We are grateful to $\mathrm{H}$. Tamura and J. Aketagawa (Tokyo Institute, Seikagaku, Tokyo, Japan) for the Limulus test. We are indebted to Mr D. Mrozek (Medical English Service, Kyoto, Japan) for reviewing this paper.

\section{References}

1. Fleming A. On a remarkable bacteriolytic element found in tissues and secretions. Proc R Soc B 1922; 93: 306-317.

2. Koncur M, Kloos WE, Schleifer K-H. The genus Micrococcus. In: Balows A, Truper HG, Dworkin M, Harder W, Schleifer K-H (eds) The prokaryotes, 2nd edn, vol II. New York, Springer-Verlag. 1992: 1300-1311.

3. Preces R, Gago E, Tejada F, Laureus AS, Alvarez-Grande J. Relapsing bacteraemia due to Micrococcus luteus in a haemodialysis patient with a Perm-Cath catheter. Nephrol Dial Transplant 1997; 12: 2428-2429.

4. Albertson D, Natsios GA, Gleckman R. Septic shock with Micrococcus luteus. Arch Intern Med 1978; 138: 487-488.

5. Wharton M, Rice JR, McCallum R, Gallis HA. Septic arthritis due to Micrococcus luteus. J Rheumatol 1986; 13: 659-660.

6. Dürst UN, Bruder E, Egloff L, Wurst J, Schneider J, Hirzel HO. Micrococcus luteus: Ein seltner Erreger einer Klappenprothesenendokarditis [a rare pathogen of valve prosthesis endocarditis.] Z Kardiol 1991; 80: 294-298.

7. Glupczynski Y, Lagast H, Van der Auwera $\mathrm{P}$ et al. Clinical evaluation of teicoplanin for therapy of severe infections caused by gram-positive bacteria. Antimicrob Agents Chemother 1986; 29: 52-57.

8. Seifert H, Kaltheuner M, Perdreau-Remington F. Micrococcus luteus endocarditis: case report and review of the literature. Zentralbl Bakteriol 1995; 282: 431-435.

9. Fosse T, Peloux Y, Granthil C, Toga B, Bertrando J, Sethian M. Meningitis due to Micrococcus luteus. Infection 1985; 13: $280-281$.

10. Selladurai BM, Sivakumaran S, Aiyar S, Mohamad AR. Intercranial suppuration caused by Micrococcus luteus. $\mathrm{Br} J$ Neutrosurg 1993; 7: 205-208.

11. Souhami L, Feld R, Tuffnel PG, Feller T. Micrococcus luteus pneumonia: a case report and review of the literature. Med Pediatr Oncol 1979; 7: 309-314.

12. Monodane T, Kawabata Y, Takada H. Micrococcus luteus cells and cell walls induced anaphylactoid reactions accompanied by early death and serum cytokines in mice primed with muramyl dipeptide. FEMS Immunol Med Microbiol 1997; 17: 49-55.

13. Ghuysen J-M, Bricas E, Lache M, Leyh-Bouille M. Structure of the cell walls of Micrococcus lysodeikticus. III. Isolation of a new peptide dimer, $N^{\alpha}$-L-analyl- $\gamma$-( $\alpha$-D-glutamyl-glycine)]-Llysyl-D-alanyl- $N^{\alpha}$-[L-alanyl-( $\alpha$-D-glutamyl-glycine)]-L-lysyl-Dalanine. Biochemistry 1968; 7: 1450-1460. 
14. Schleifer KH, Kandler O. Micrococcus lysodeikticus: a new type of cross linkage of the murein. Biochem Biophys Res Commun 1967; 28: 965-972.

15. Hase S, Matsushima Y. Structural studies on a glucosecontaining polysaccharide obtained from cell walls of Micrococcus lysodeikticus. III. Determination of the structure. $J$ Biochemistry 1972; 72: 1117-1128.

16. Nasir-ud-Din, Jeanloz RW. The chemical structure of a fragment of Micrococcus lysodeikticus cell-wall. Carbohydr Res 1976; 47: 245-260.

17. Perkins HR. A polymer containing glucose and aminohexuronic acid isolated from the cell walls of Micrococcus lysodeikticus. Biochem J 1963; 86: 475-483.

18. Dziarksi R. Effects of peptidoglycan on the cellular components of the immune system. In: Seidl PH, Schleifer K-H (eds) Biological properties of peptidoglycan. Berlin, Walter de Gruyter. 1986: 229-247.

19. Kotani S, Narita T, Stewart-Tull DES et al. Immunoadjuvant activities of cell walls and their water-soluble fractions prepared from various gram-positive bacteria. Biken $J$ 1975; 18: $77-92$.

20. Kotani S, Watanabe Y, Kinoshita F, Kato K, Perkins HR Immunoadjuvant activities of the enzymatic digests of bacterial cell walls lacking immunoadjuvancy by themselves. Biken $J$ 1977; 20: 87-90.

21. Nagao S, Akagawa KS, Okada F et al. Species dependency of in vitro macrophage activation by bacterial peptidoglycans. Microbiol Immunol 1992; 36: 1155-1171.

22. Monodane T, Matsushima Y, Kotani S. Demonstration of the physiological role of autolysis by a comparative study with a wild-type and its non-autolytic mutant of Micrococcus lysodeikticus (luteus) cultivated with externally added proteolytic enzymes. Microbiol Immunol 1978; 22: 67-80.

23. Monodane T, Matushima Y, Hirachi Y, Kotani S. Cell wall autolysis in $\log$ phase cells of Micrococcus lysodeikticus (luteus). Microbiol Immunol 1978; 22: 57-66.

24. Monodane T, Yamashita S, Hase S, Fukui K. Laser Raman spectroscopy of teichuronic acid on Micrococcus lysodeikticus (luteus) cell walls. Cell Mol Biol 1983; 29: 121-125.

25. Monodane T, Kusamichi M, Tokunaga M, Torii M. Cell surface of Micrococcus luteus: Chemical treatment of the cells and teichuronic acids on the surface. Microbiol Immunol 1989; 33: $165-174$

26. Monodane T, Tokunaga M, Torii M. Cell surface of a tetradsforming mutant of Micrococcus luteus: chemical treatment of the cells and teichuronic acids on the surface. Microbiol Immunol 1990; 34: 65-72.

27. Monodane T, Tokunga M, Uesugi Y, Torii M. Chemical treatments of the cell packets induced from a Micrococcus luteus mutant and teichuronic acids on the packet surface. Cell Mol Biol 1990; 36: 101-106.

28. Monodane T, Hara S, Matsushima Y. Studies on the substrate specificity of egg white lysozyme. V. Subsites C and D in the active site. J Biochem 1972; 72: 1175-1183.

29. Obayashi T, Tamura H, Tanaka S et al. A new chromogenic endotoxin-specific assay using recombinant Limulus coagulation enzymes and its clinical applications. Clin Chim Acta 1985; 149: 55-65.

30. Goldstein IJ, Hay GW, Lewis BA, Smith F. Controlled degradation of polysaccharides by periodate oxidation, reduction and hydrolysis. In: Whistler RL, BeMiller JN, Wolfrom ML (eds) Methods in carbohydrate chemistry, Vol 5, General polysaccharides. New York, Academic Press. 1965: 361-370.

31. Galanos C, Lüderitz O, Westphal O. Preparation and properties of a standardized lipopolysaccharide from Salmonella abortus equi (Novo-Pyrexal). Zentralbl Bakteriol Hyg A 1979; 243: 226-244.

32. Takada H, Kawabata Y, Tamura $\mathrm{M}$ et al. Cytokine induction by extracellular products of oral viridans group streptococci. Infect Immun 1993; 61: 5252-5260.

33. Monodane T, Yamashita S, Fujimori K, Tokunaga M. LaserRaman spectroscopy of cell walls from Micrococcus luteus (lysodeikticus) with special reference to cell wall typing. Cell Mol Biol 1987; 33: 407-411.

34. Torii M, Sakakibara K, Iida S, Kobayashi K, Hase S, Matsushima Y. Immunological studies on a polysaccharide from Micrococcus lysodeikticus containing glucose and $\mathrm{N}$ acetyl-mannosaminuronic acid. Biken $J$ 1973; 16: 11-16.

35. Gassner GT, Dickie JP, Hamerski DA, Magnuson JK, Anderson JS. Teichuronic acid reducing terminal $\mathrm{N}$-acetylglucosamine residue linked by phosphodiester to peptidoglycan of Micrococcus luteus. J Bacteriol 1990; 172: 2273-2279.

36. Hase S, Matsushima Y. The structure of the branching point between acidic polysaccharide and peptidoglycan in Micrococcus lysodeikticus cell wall. J Biochem 1977; 81: 11811186.

37. Nasir-ud-Din, Lhermitte M, Lamblin G, Jeanloz RW. The phosphate diester linkage of the peptidoglycan polysaccharide moieties of Micrococcus lysodeikticus cell wall. J Biol Chem 1985; 260: 9981-9987.

38. Siddiqui M, Qureshi MH, Malghani MAK, Walker-Nasir E, Fayyaz-ud-Din, Nasir-ud-Din. Structure of a Micrococcus lysodeikticus cell wall fragment containing phosphorylated sugars. Biochem Int 1992; 26: 509-519.

39. Bashford CL, Alder GM, Menestrina G, Micklem KJ, Murphy JJ, Paster Nak CA. Membrane damage by hemolytic viruses, toxins, complement and other cytotoxic agents. A common mechanism blocked by divalent cations. J Biol Chem 1986; 261: $9300-9308$

40. Elferink JGR. Changes of plasma membrane permeability in neutrophils treated with polycations. Inflammation 1991; 15: $103-115$.

41. Hoshino K, Takeuchi O, Kawai T et al. Cutting edge: Toll-like receptor 4 (Tlr4)-deficient mice are hyporesponsive to lipopolysaccharide: evidence for TLR4 as the Lps gene product. $J$ Immunol 1999; 162: 3749-3752.

42. Poltorak A, He X, Smirnova I et al. Defective LPS signaling in $\mathrm{C} 3 \mathrm{H} / \mathrm{HeJ}$ and $\mathrm{C} 57 \mathrm{BL} / 10 \mathrm{ScCr}$ mice: mutations in Tlr4 gene. Science 1998; 282: 2085-2088.

43. Qureshi ST, Lariviére L, Leveque G et al. Endotoxin-tolerant mice have mutations in Toll-like receptor 4 (Tlr4). J Exp Med 1999; 189: 615-625.

44. Takeuchi O, Hoshino $\mathrm{K}$, Kawai $\mathrm{T}$ et al. Differential roles of TLR2 and TLR4 in recognition of Gram-negative and Gram positive bacterial cell wall components. Immunity 1999; 11: 443-451.

45. Fischer W. Bacterial phosphoglycolipids and lipoteichoic acids. In: Kates M (ed) Handbook of lipid research: 6 Glycolipids, phosphoglycolipids, and sulfoglycolipids. New York, Plenum Press. 1990: 123-234.

46. Sutcliffe, IC, Shaw N. Atypical lipoteichoic acids of grampositive bacteria. J Bacteriol 1991; 173: 7065-7069.

47. Shibazaki M, Kawabata Y, Yokochi T, Nishida A, Takada H, Endo Y. Complement-dependent accumulation and degradation of platelets in the lung and liver induced by injection of lipopolysaccharides. Infect Immun 1999; 67: 5186-5191.

48. Siegel J, Osmand AP, Wilson MF, Gewurz H. Interactions of Creactive protein with the complement system. II. C-reactive protein-mediated consumption of complement by poly-L-lysine polymers and other polycations. J Exp Med 1975; 142: 709-721. 